\title{
AN ANALYSIS OF THE CHANGING ROLE OF ISTANBUL AS A MEGACITY IN THE WORLD
}

\author{
Muhammed Ziya PAKÖZ (Gebze Technical University, Faculty of Architecture, Department of \\ City and Regional Planning, mzpakoz@gtu.edu.tr); Turkey \\ Ahmet BAŞ, (Abdullah Gül University, Faculty of Architecture, Department of Urban and \\ Regional Planning, ahmet.bas@agu.edu.tr); Turkey \\ Fatih EREN (Konya Technical University, Faculty of Architecture and Design, Department of \\ City and Regional Planning, feren@ktun.edu.tr); Turkey
}

\begin{abstract}
Istanbul is a unique part of the world because of not only its history, but also its function as a bridge from the point of economic, social and cultural interrelations. There are many cities, which are settled near a water source; however, Istanbul is the only city that is settled between two continents and two seas. All these features create some opportunities and threats for the city in terms of hinterland relations and the spatial structure.

This paper aims to find out the economic, social and cultural impact of globalization on the spatial structure and the hinterland relations of Istanbul while discussing the city's contradictory positions as an edge of Europe and as a bridge between the East and the West. Within this scope, we made a multiscale analysis considering interregional and inter-urban relations and their socio-spatial imprints within the boundaries of the city. Firstly, we made a comparative analysis to understand the changing position of Istanbul in the world in the 21st century by using global and regional indexes. Secondly we examined the change in the hinterland relations of the city by investigating the flows of people, goods, services and ideas between other regions / cities and the city of Istanbul in time. Thirdly, we traced the spatial imprints of these flows and interactions within the city in terms of relocations and displacements.

Our study shows the growing importance of the city not only as a part of Europe but also as a node and bridge for the globalized world while emphasising socio-cultural and socio-economic tensions within the city as a result of this process.

\section{Keywords}

Istanbul, globalization, global city indexes, spatial structure, hinterland relations.

\section{Introduction}

Istanbul is one of the fastest-growing metropolitan areas not only in its region but also in the world. It functions as a bridge in terms of social, economic and cultural flows and transitions between continents as well as the cradle of human civilization.

Despite the changing of the capital from Istanbul to Ankara in 1923, Istanbul achieved to sustain its role as "the nation's industrial and business centre, greatest port, the focus of transportation network and the centre of cultural and intellectual life" (Göymen, 2008). For 
the last decades, Istanbul attracts millions of people from different regions in Turkey as well as from the other near and far countries from Asia to Africa (Table 1).

Table 1: Population change in Istanbul, the Marmara Region and Turkey from 2000 to 2018 (TurkStat, 2019).

\begin{tabular}{|l|c|c|c|c|c|}
\cline { 2 - 6 } \multicolumn{1}{c|}{} & $\mathbf{2 0 0 0}$ & $\mathbf{2 0 0 5}$ & $\mathbf{2 0 1 0}$ & $\mathbf{2 0 1 5}$ & $\mathbf{2 0 1 8}$ \\
\hline Istanbul & $11,076,840$ & $12,128,577$ & $13,255,685$ & $14,657,434$ & $15,067,724$ \\
\hline Marmara Region & $17,829,639$ & $19,467,417$ & $21,285,696$ & $23,403,950$ & $25,034,570$ \\
\hline Turkey & $64,729,501$ & $68,860,539$ & $73,722,988$ & $78,741,053$ & $82,003,882$ \\
\hline
\end{tabular}

Istanbul is located in the middle of the Asia, Africa and Europa. Just in a three hours flight, it could be reached 1.5 billion people. Besides Turkish Airlines (THY) widens its hinterland and starts to flight more than 350 destinations in the world. This makes Istanbul more accessible from any point of the world.

On one hand, Istanbul is an "avantgarde" city for Turkey and its region. Economic impact of Istanbul is very high. According to the Turkish Statistical Institute (TurkStat), $43 \%$ of the total taxes are collected and $55 \%$ of economic activities are produced in Istanbul. Together with adjacent cities (Kocaeli and Tekirdağ) in the metropolitan region, this ratio reaches more than $50 \%$ of taxes and $65 \%$ of economic activities in Turkey. Additionally, more than 13 million tourists visited the city in 2018.

On the other hand, not only the city of Istanbul and the rural towns within the boundaries of the city, but also other cities in Turkey and near countries such as Balkan and Middle East as well as Africans, which play an essential role supporting and providing resources of foods, labour, industrial activities, raw materials and so on to the city of Istanbul.

As well as economic situation, social and cultural transition between the different groups makes the city unpredictable core of the region. Different ethnic/religious groups and immigrants live in the city together. Beyond all that, Istanbul is a big exporter of the Turkish TV series to the neighbours of the country especially in the Middle East and the Balkans.

In this paper, we examined how globalization process affected the city's socio-economic and socio-political position within the world, and how this change influenced socio-spatial processes within the city. In the second chapter following the introduction, the most popular global city indices including Istanbul were picked and the changing position of Istanbul in the world has been scrutinized. In the third chapter, changing hinterland relations of the city in terms of flows of people, capital, goods, services and ideas/cultures; and their socio-spatial imprint within the city were discussed.

\section{The Changing Position of Istanbul in the World}

Istanbul is included in almost all international studies comparing world cities. The main cities where Istanbul is compared in various categories in the Global City Indices are New York, London, Tokyo, Paris, Frankfurt, Zurich, Dubai, Beijing, Seoul, Hong Kong, Bangkok, Singapore, Sydney, Vancouver and Los Angeles. These cities both share and compete with each other in the world city network. 
Istanbul attracts people from almost every point of the world. The recognition of a global city encourages international organizations to think and produce new projects in that city. According to the Global Power City Index (2018), cities like Doha, Dubai, Beijing and Bangkok make great efforts to attract people's attention, while Istanbul can naturally attract people without special effort. Istanbul is the 34th most powerful city in the world, with high global accessibility and a preferred stopping point for international travel (MMF, 2018). Istanbul is an advantageous transfer and maintenance point in terms of location for both air passengers and airline companies in long-distance transfer flights in the east-west and north-south axis in the world. Istanbul has a strong transportation and communication infrastructure. Ongoing and planned large-scale regional transport projects strengthen the infrastructure and renewal of Istanbul and neighbouring cities. The city has something to appeal to everyone in the world. According to Kearney's Global Cities 2019 Report, Istanbul ranks 26th among 135 most influential global cities (Kearney, 2019).

The business world in Istanbul is very active and lively. The indices reveal that Istanbul can attract qualified people from Turkey and abroad. This is a very important feature for Istanbul, because the performance of global cities is rapidly increasing when it can attract a qualified young population from the world to live and work. According to the JLL Global 300 Cities Index, Istanbul ranks 17th in terms of population, 13th in terms of economic size and 19th in terms of commercial attractiveness among 300 global cities (JLL, 2019).

Istanbul's foreign trade volume is around 195 billion dollars (TurkStat, 2016). According to the data of the Ministry of Commerce, Istanbul exported USD 34 billion and imported USD 57 billion in 2018 (Ministry of Commerce, 2018). With these characteristics, Istanbul is one of the 20 most important business and trade cities in the world according to the 2016 Commercial Attraction Index. In addition, for many years, Istanbul has been shown as one of the leading investment cities by all credit rating agencies. According to World Bank 2015 data, with an economic size of 349 billion dollars, Istanbul has a larger economy than 130 countries in the world (for example, Pakistan, Chile, Ireland, Finland, Portugal and Greece). Having a stock exchange in global city indices is shown as an element that reveals the economic impact power of a global city. In this context, the presence of BORSA iSTANBUL adds a great strength to the economic attractiveness and image of the city. The cost of living in Istanbul is relatively low compared to many global cities (eg Dubai, New York, etc.). In the 2018 survey of the Mercer company, which ranked 209 global cities according to the high cost of living, Istanbul was ranked 154th. According to UN Habitat Urban Data 2016 data, food and clothing prices, urban transportation costs, urban utility bill costs and leisure time costs are among the factors that reduce the cost of living.

The quality, speed and environment of hospital services in Istanbul are better than all other global cities (Numbeo, 2019). The number of visitors to the city to receive qualified health services and treatment has increased in recent years. Compared to many global cities, there are many historical and natural areas to visit in Istanbul (and nearby neighbouring cities). These features make Istanbul stand out in the global competition and make it strong.

According to the global city index data, there are two important issues that have left Istanbul weaker in global competition. First, Istanbul is not yet able to produce sufficiently effective projects and projects on environment, energy and waste. There is a need to make strong moves in the city in terms of clean energy, environment and recycling, not only in order to 
be ahead of the economic race, but also to make Istanbul a liveable place for both people and other living things. Evaporation increases, scarce ground and surface water resources decrease, water quality decreases, vegetation cover changes, and seasonal imbalances in temperature and rainfall amounts occur due to global climate change and global warming. Like many other world cities, Istanbul is also affected from changing environmental conditions. Protecting natural resources and nature should be kept on the agenda as much as economic development in Istanbul in order to prevent Istanbul from being affected by climatic changes and global warming in a longer term. Turkey has its signature under the international agreement on global climate change. Therefore, the country must adopt a strong attitude on this issue. The lack of open and green spaces in the city and the intense structuring in Istanbul are the major factors that downgrade Istanbul in global city indices.

Second, Istanbul (including patent, utility model, trademark, industrial design and registration) is unable to produce enough original information and manage the global flow of information. According to the Networked Society City Index 2016, which researches the sustainable development of global cities in the information and communication sector, Istanbul is the 22nd most integrated city in the global network and its performance in this area is rapidly increasing (Ericsson, 2016). The inability to keep the circulation of useful information around the world is the biggest obstacle for Istanbul to become a leading and efficient city in the world in terms of $R \& D$ studies and patents.

Istanbul, whose transportation and communication infrastructure has been renewed, strengthened and expanded year after year, has the potential to be a central city that manages all global flows between the three continents. Anatolia and Turkey's European territory of the new road, sea, rail and air are connected with the new projects. This facilitates and accelerates the flows of people, goods, services, information and finance between Europe, Asia and Africa.

Not only in terms of land transportation, but also in terms of air transportation, Istanbul has a great importance both at national and international level (Eren, 2018). Turkey's air cargo operations are mainly carried out via Istanbul and Marmara region. Istanbul Atatürk Airport ranks 30th in the airport rankings according to cargo traffic in the world. Due to its location, Istanbul can reach most of the continents of Asia, Europe and Africa within a short flight distance of three hours. Istanbul New Airport will make Istanbul the centre of both the country and the region in terms of air cargo logistics. With an annual cargo capacity of 6 million tons, the new airport crosses Hong Kong, Memphis, Shanghai, Seoul, Dubai, Tokyo and Frankfurt airports in terms of volume. The fast connection of the new airport by road and sea, and the strong integration of transportation in the city are of great importance in terms of the international competitiveness of the new airport.

There are many large-scale transportation and infrastructure investments in Istanbul. These investments increase the interaction and trade relations of Turkey with Asia, Middle East, Mediterranean and the European countries and relieve Istanbul's urban transport and traffic. Istanbul is a consumption and distribution focus where $53 \%$ of the production of logistics activities occurs in Turkey. These activities contribute 32 billion TL annually to the national economy (IBB, 2017). Therefore, Istanbul is the most important locomotive city in the development of trade, industry, finance and tourism sectors. 
With the Istanbul Stock Exchange, Istanbul is Turkey's main financial centre. However, the city aims to become an international financial centre. This objective is clearly emphasized in the 2009 Strategy and Action Plan, the Vision 2023 document and the 10th Development Plan. In line with this objective, the international financial centre, which has a physical infrastructure in Ataşehir, is expected to provide new jobs for 30,000 people. In 2016, 104,000 people are employed in finance and insurance activities in Istanbul. Therefore, there are 7 jobs per 1000 people in the financial sector in Istanbul. This ratio is below the average standard in international financial centres. Therefore, the financial sector in the city needs to be expanded by following a special strategy. If the financial and insurance sector in Istanbul grows by $4.7 \%$ each year, in 2036 a total of 261,000 people will become employable in the sector. When Istanbul's capacity in the financial sector increases, this will also help the growth of other sectors in the country.

Istanbul has the potential to become a headquarters for financial investors in the Arabian Peninsula, the European Union and Russia. This can be achieved by creating the most advanced technological infrastructure in Istanbul, facilitating access to innovative technology and reducing costs.

For foreign investors, Turkey is considered as a country that is difficult to do business. The World Bank Ease of Doing Business Index based on 2017 data, Turkey is ranked 69 among 190 countries. Unfortunately, the new investment incentive system does not include incentives for the rapid growth and internationalization of high value added sectors such as finance and IT in Istanbul.

Istanbul is a national and international trade centre. 69 out of every 1000 people in the city are employed in wholesale and retail trade sector. This ratio shows that Istanbul is behind Dubai (94) but ahead of Hong Kong (68) and Singapore (63) to become a global commercial centre. Istanbul is also very close to its competitors in the food and beverage sector. In 2016, 284,000 people are employed in this sector in Istanbul. Therefore, 19 out of every 1000 people work in this sector. 25 out of every 1000 people in Singapore and 29 out of 1000 people in Dubai are employed in this sector. Istanbul has the potential to attract many more international students in the higher education sector. Today, 25,000 teaching staff is employed in this sector.

To sum up, Istanbul has a number of strong points/advantages to compete with other global cities such as its location, transport infrastructure, young population, and lower costs of living while it has some weaknesses to eliminate such as its environmental conditions, quality of life and lack of innovations to lead the world.

\section{The changing hinterland relations and socio-spatial organization}

\subsection{Flows of people: Demographic transition}

Turkey was mostly "a country of emigration" during the second half of the $20^{\text {th }}$ century. From the beginning of the $21^{\text {st }}$ century, the country has become a cross-road point not only for irregular migrants from Asian countries such as Afghanistan, Pakistan, Bangladesh, Iraq, Iran but also for EU specialist and retirees and regular/irregular migrants from the former Soviet Bloc countries. 
Turkey signed Convention Relating to the Status of Refugees in 1951. Today, Turkey, known as migration and asylum country for many years due to policies, are faced with difficulties. However, Turkey's traditional immigration policy nowadays, nation-building concerns, and maintaining a homogeneous national identity was largely shaped by efforts. Turkey's immigration policy in recent years, necessitate the replacement of traditional policies (Kirişçi, 2007).

In 1923 (the proclamation date of the Turkish Republic) the city of Istanbul had a nearly 700.000 population. Its growth continued relatively until the 1970 s, when it reached about two million (TurkStat, 2018). After that, accelerated economic development, which fuelled strong internal migration especially from the middle and eastern Black Sea and Eastern Anatolia regions of Turkey, led to a rapid expansion of both population and built-up area. By the end of 2018, the city had a population of more than 15 million on a territory that covers $5.461 \mathrm{~km}^{2}$. Currently, about two-thirds of the population ( 9 million) live on the European side, and one-third (6 million) across the Bosporus on the Anatolian side (TurkStat, 2018).

While there were 20 universities and 198.612 students (associate-bachelor-masterdoctorate) in Istanbul in the 2000-2001 education period, the number of universities increased to 57 and the number of university students to 774.350 in 2018-2019 (YOK, 2019). The number of university students in Istanbul corresponds to $41 \%$ of the total number of university students in Turkey (1.888.557 in total). In the 2017-2018 period, the number of foreign students studying at the universities in Istanbul is 35,735 which refers the $28.5 \%$ of all foreign students in Turkey (YOK, 2019).

According to the TurkStat, 46.509.314 tourists and sojourners have visited Turkey in 2018. Of these, 18.643.175 visited Istanbul as a tourist/visitor (TurkStat, 2019a). There are 1.013.618 foreigners with a residence permit in Turkey, and 517.997 foreigners $151.1 \%$ of total foreigners) are located in Istanbul (DGMM, 2019a). Similarly, there are 3.62 million Syrians under temporary protection in Turkey; and 547.535 Syrians (15\% of total Syrians in Turkey) are settled in Istanbul (DGMM, 2019b).

While the number of international immigrants migrating to Istanbul in 2000 was 54.644, as of the end of 2017, this number reached 166.044. Of the 166.044 people who came to Istanbul in 2017 by international migration, 148.722 were foreign nationals. In 2017, international net migration to Istanbul was 90.195 (TurkStat, 2019b). As it is seen, Istanbul has attracted $35 \%$ of all international immigrants (466.333 all over Turkey) in 2017. In addition, $42.4 \%$ of international net migration was realized in Istanbul.

In terms of internal migration, the opposite is the case. In 2015-2018, the emigration from Istanbul is higher than immigration to the city. In this period, net migration was realized as 287.600 (TurkStat, 2019b).

Table 2: The population / visits and the share of Istanbul in Turkey

\begin{tabular}{|llccc|}
\hline & (Year, Source) & Istanbul & Turkey & $\%$ \\
\hline Population & $(2018$, TurkStat) & 15067724 & 82003882 & $\mathbf{1 8 , 3 7}$ \\
University Students & $(2018-2019$, YOK) & 774350 & 1888557 & $\mathbf{4 1 , 0 0}$ \\
International Tourists / Sojourners & $(2018$, TurkStat) & 18643175 & 46509314 & $\mathbf{4 0 , 0 8}$ \\
Temporary residents & $(2019$, DGMM) & 517997 & 1013618 & $\mathbf{5 1 , 1 0}$ \\
\hline
\end{tabular}




\begin{tabular}{|llcrr|}
\hline International Immigrants & (2017, TurkStat) & 166044 & 466333 & $\mathbf{3 5 , 6 1}$ \\
International Net Migration & (2017, TurkStat) & 90195 & 212693 & $\mathbf{4 2 , 4 1}$ \\
Temporary Protection (Syrians) & $(2019$, DGMM) & 547535 & 3626820 & $\mathbf{1 5 , 1 0}$ \\
Domestic Passengers (Airports) & $(2018$, DHMI) & 41795577 & 112911108 & $\mathbf{3 7 , 0 2}$ \\
International Passengers (Airports) & $(2018$, DHMI) & 60780029 & 97587056 & $\mathbf{6 2 , 2 8}$ \\
\hline
\end{tabular}

As can be seen from the Table 2, the gravity of Istanbul, which hosts $18 \%$ of Turkey's population, is much higher than its population. The city has become a centre of attraction for university students, tourists, sojourners, international immigrants and refugees. This attraction has dramatically changed the demographic structure of the city. In the central areas of the city, some of the dwellings inhabited by local residents have been converted into motels / pensions / dormitories, and some have been converted into dwellings where students and refugees reside. The fact that housing stock in the central areas of the city is older than the peripheral areas while the rental and sales values are higher in addition to the parking and security problems in these areas influenced the preferences of the local people, who can find new apartment buildings or reside in gated communities in the peripheral areas. As a result, the demographic structure that emerges in the central areas of the city causes the alienation of the citizen to the city.

The number of universities in the city has increased rapidly in the last 15 years and most of the new universities are concentrated in Fatih, Beyoğlu, Beşiktaş, Şişli, Üsküdar, Kadıköy districts, where can be described as the historical core of the city (Figure 1). Fatih district is also the most preferred area for international immigrants and Syrians under temporary protection. Fatih and Beyoğlu are also the centres of touristic activities.

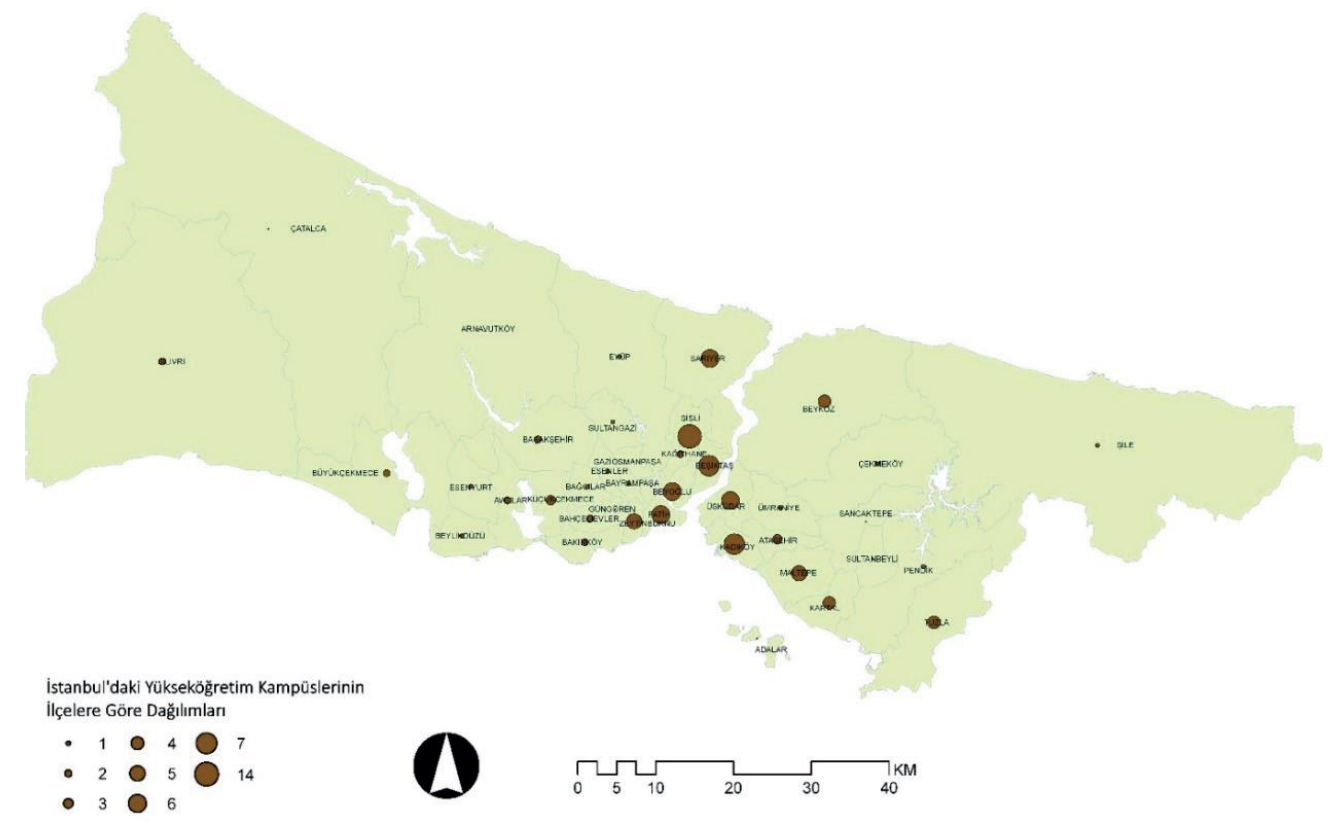

Figure 1: Distribution of Higher Education Campuses in Istanbul by District-2015 (Arlı, 2016a).

In addition, gentrification zones have started to be formed in the central areas of the city, especially in some districts of Beyoğlu, Şişli and Beşiktaş. The transformation in these regions also resulted in the displacement of the old inhabitants of the city. 
In summary, Istanbul's adventure of being a centre of attraction and a global city on an international level has led to a change in the demographic structure of the city. The movement of the city dwellers from the centre to the periphery and out of the city, increasing visibility of tourists, students, expats, intellectuals, single white-collar employees in the central areas of the city. In addition, low-quality houses in the central areas of the city, where have not yet been transformed, has become a shelter for the Syrians under temporary protection.

\subsection{Flows of capital, goods and services: spatial re-organization}

Despite numerous headwinds, unsuccessful military coup and adverse shocks, "Turkey's real GDP has grown by more than $34 \%$ over the past 5 years, faster than any other OECD country except for Ireland and only slightly less than China and India"(OECD, 2019). Turkey's business sector showed one of the highest investment rates in the OECD countries. However, even there is a big economic fluctuation in the second part of 2018 , which triggered a recession in the second half of the year (Figure 2), strong fiscal and quasi-fiscal stimulus have moderated the contraction in early 2019.

Istanbul is the capital of economy in Turkey informally. All financial centres, banks, insurance companies etc. are located in the city. It has provided more than $40 \%$ of Turkish taxes and nearly $55 \%$ of economic activities in Turkey (IBB, 2017).

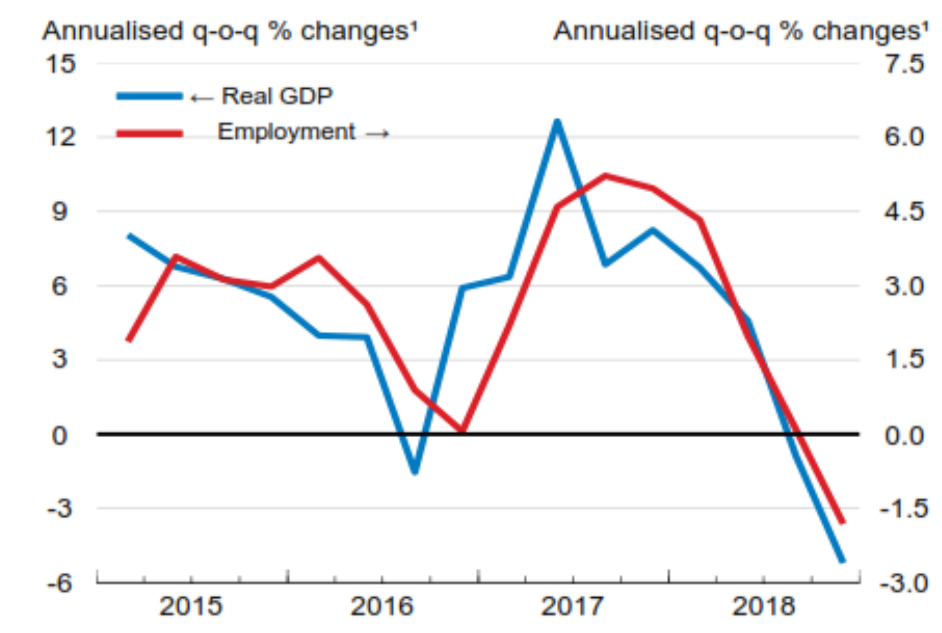

\section{Three-quarter moving average. \\ Source: OECD Economic Outlook 105 database; and Refinitiv.}

Figure 2: Turkeys' real GDP and employment distribution between 2015 and 2018.

Thanks to rapid economic growth, numbers of immigrants from all parts of Turkey and from neighbour countries migrated to Istanbul in one of the world's fastest migration rate. This flow of migrants put the physical infrastructure of the city under great pressure and caused great congestion costs. As Göymen points out in his study, the generally unqualified waves of migrants continued to come to Istanbul, putting pressure on housing stocks and physical and social infrastructure; Increased congestion forces the environmental bearing capacity to its limits. (Göymen, 2008).

Istanbul is also one of the main cities of media and cinema industries in Turkey. The ongoing boom period, which remains largely unknown to the majority of casual viewers in the West, 
began in 1999. Since then, Turkish drama serials have been seen across the rest of the world by billions of people. To put this surge into context, in 2004 Turkish TV exports were worth $\$ 10,000$. That figure grew to $\$ 350$ million by 2017 . The aim is to hit the eye-watering sum of $\$ 2$ billion by 2023 with TV dramas expected to make up over half that total (Looch, 2019).

Human movements and demographic changes in the city have progressed in parallel with goods, services and capital flows. These trends have led to significant changes in the spatial organization of the city.

The traditional business centre of the city (Historic Peninsula-Beyoğlu) first expanded northward (Şişli-Levent-Maslak); later, a financial centre was established on the Anatolian side of Kadıköy-Ataşehir-Kozyatağı axis. As a result of the expansion of the traditional centre and the formation of new centres, the number of skyscrapers has started to increase rapidly in the central areas of the city and sub-centre areas. On one hand, newly constructed skyscrapers have an impact that strengthens Istanbul's global urban image. On the other hand, they have been criticized for their negative impact on the city's historical skyline, as well as the traffic load it brings to the city and deepening the socio-spatial differentiation in the city. The rapid increase in the number of skyscrapers brought about the Dubaization / Manhattanization discussions.

Global brand chains spread from the centre to the peripheral areas thanks to the rapidly increasing number of shopping malls in the city. The number of shopping centres in the city, which was 25 in 2004, reached 80 in 2014. Şişli, Beylikdüzü and Esenyurt on the European side, Ataşehir and Ümraniye on the Anatolian side were the most preferred districts of the new shopping malls (Çakır Zeytinoğlu et al., 2016).

The fact that this trend and increasing land values in the city started to put pressure on the industrial areas within the city resulted in the decentralization of the industry in the eastwest direction (Kocaeli-Bursa-Tekirdağ). As an important industrial axis of the city, Basin Ekspress Road today is mostly used with services such as shopping centres, hotels, offices and residences.

The symbols of change and transformation in the integration process of Istanbul to the global world appear as "mega projects". Yavuz Sultan Selim Bridge (the $3^{\text {rd }}$ Bosporus Bridge), which was completed in 2016, the Istanbul Airport, which was put into service in 2018 , and Kanal Istanbul (the waterway project) planned to be constructed as an alternative to the Bosporus are the three most important and most debated mega projects in this period. All three projects were supported by advocates of economic integration with the global world and criticized for increasing the pressure on the city's natural resources and shifting the direction of development towards forest areas in the north. These projects have become important platforms in which socio-political tensions in the city have come to light (Baş et al., 2018). 

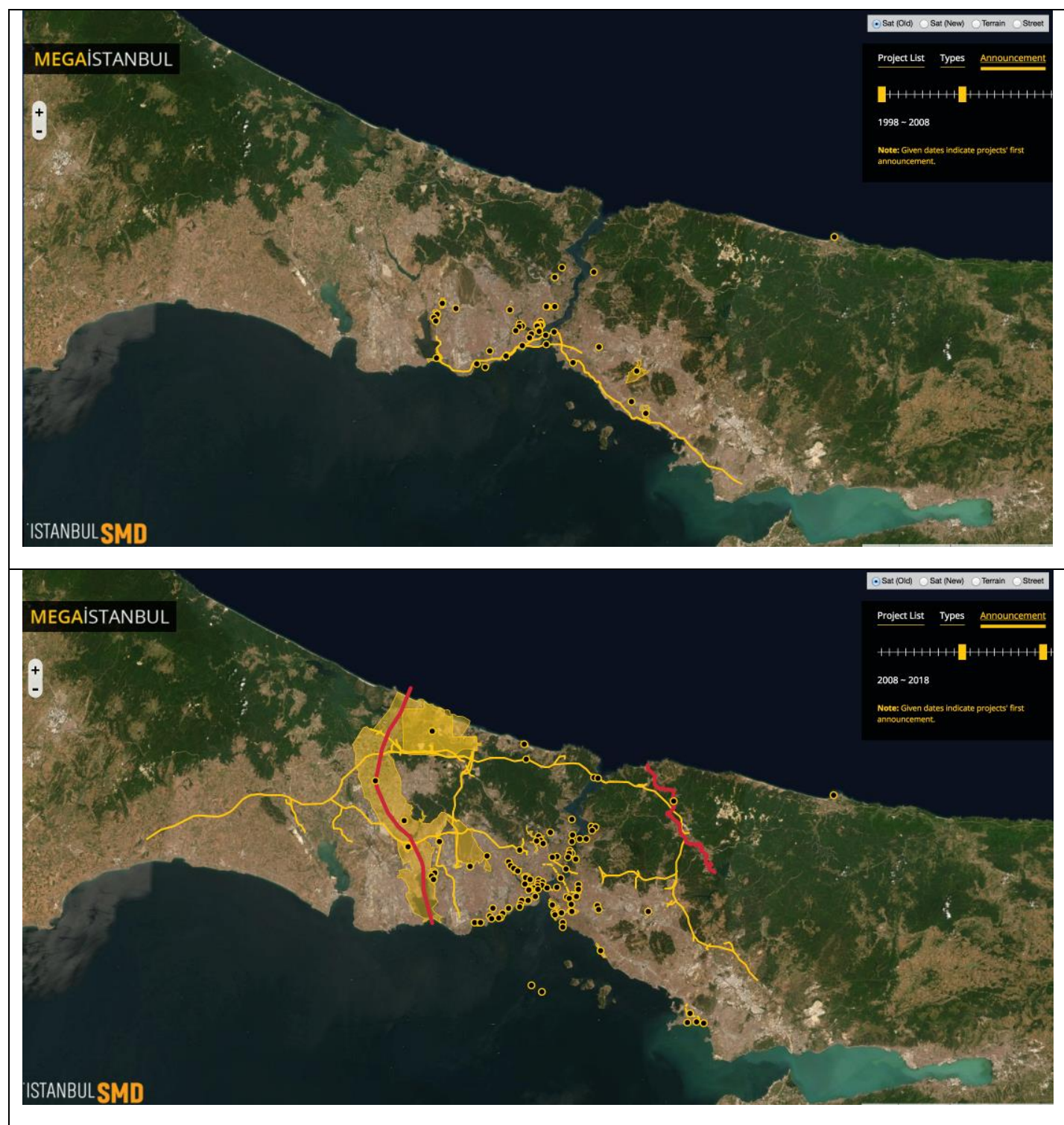

Figure 3: Planned / Announced mega projects in Istanbul between 1998-2008 (above) and 2008-2018 (below) (IstanbulSMD, 2019).

The mega projects announced to the public between 1998 and 2018 are shown on the map of Istanbul (Figure 3). In the first decade, mega projects envisaged both in the centre of the city and on the east-west axis. However, the number of these projects has boomed as the integration process into the global world has accelerated; and the location of these projects, both growing in number and area, shows that the direction of development of the city has also changed.

It is also possible to follow the rapid development and change of the city through the land use data of CORINE (Coordination of Information on the Environment) shared by the Ministry of Agriculture and Forestry. It can be read from the 2018 data that mobility started with the new airport and highways / bridges in the north of the city (Figure 4). 


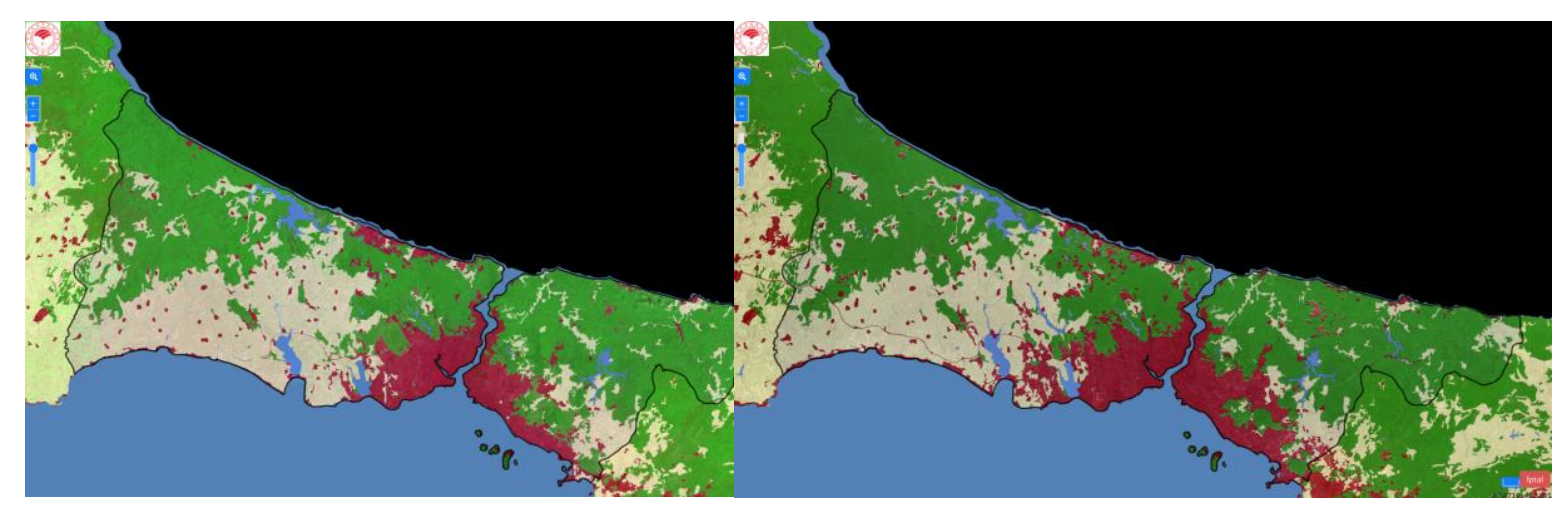

The year of 1990

The year of $\mathbf{2 0 0 0}$

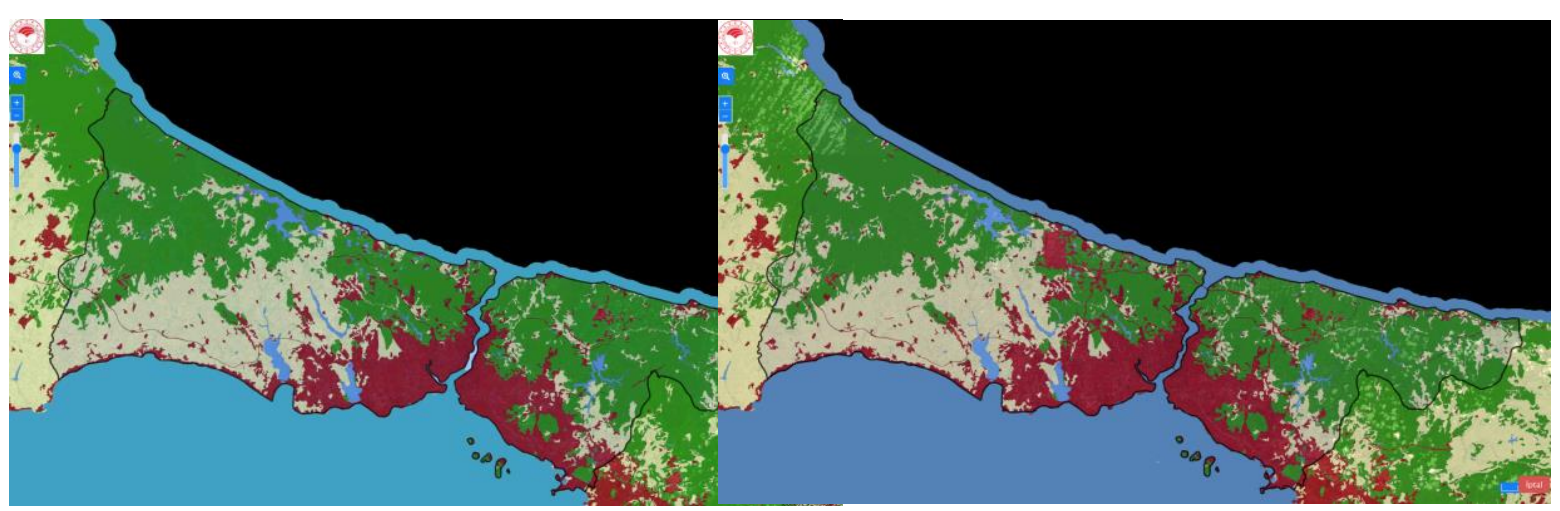

The year of 2012

The year of 2018

Figure 4: The changing land use of Istanbul between 1990 and 2008 (CORINE Land Use Data) (TOB, 2019).

To sum up, Istanbul's integration with the global world has led to socio-spatial transformations in the central areas of the city, and to the expansion of the city in the eastwest and north directions and forcing natural thresholds.

\subsection{Flow of cultures and images: socio-cultural transition}

In addition to the flows of people, goods, capital and services, it is seen that Istanbul is on its way to becoming the centre of the cultural industry and expanding its area of influence. Cultural interaction has occurred in two ways. First, a mutual cultural exchange has become possible through numerous cultural events, exhibitions, festivals and congresses; and second, thanks to the Turkish TV series, a cultural hinterland has been formed in a wide geography especially in the Balkans, the Middle East and Latin America.

Turkish TV series have created a cultural hinterland in the geographies where they are exported, and the interest and curiosity of the audience watching the series has increased. According to Ozcan and Anaz, Turkish TV series and films have positively impacted Turkey's visibility abroad (Ozcan and Anaz, 2016). Moreover, there are some touristic organizations organized only to visit the sets (Melamed, 2019; Gürmen, 2016; Sobecki, 2010).

Turkish TV series are also very effective in the Middle East and the Asian countries. For instance, A study conducted in Pakistan revealed that exposure to foreign culture by watching its series and programs, had a profound impact on Pakistani youth, thus affecting cultural identity, norms and values. (Raza, 2015). 
Magnificent Century (Muhteşem Yüzyıl), an epic historical drama launched in 2011, that found audiences beyond Latin America and the Middle East. At its peak the series, which tells the story of $16^{\text {th }}$ century Ottoman sultans, was broadcast in over 40 countries with more than 200 million viewers worldwide (Looch, 2019). Ertugrul Resurrection (Diriliş Ertuğrul) is one of the most popular Turkish TV series all over the world. It has shown in more than 50 countries as well as in Netflix.

The city was selected as the European Capital of Culture in 2010. According to the International Congress and Convention Association (ICCA), Istanbul is one of the most important destinations that host international congresses. Although Istanbul, one of the top 10 cities hosting the most international community in the world in 2008-2012, declined by ten places as a result of the terrorist incidents and coup attempt in 2013-2017 period, the city has still an important attraction power (Table 3 ).

Table 3: Number of international meetings per city between 1963 and 2017 (ICCA, 2018).

\begin{tabular}{|c|c|c|c|c|c|c|c|c|c|c|c|c|}
\hline Rank & Country & 63-67 & $68-72$ & $73-77$ & $78-82$ & 83-87 & $88-92$ & 93-97 & 98-02 & 03-07 & 08-12 & $13-17$ \\
\hline 1 & Paris & 90 & 95 & 125 & 152 & 178 & 261 & 299 & 393 & 605 & 885 & 1,079 \\
\hline 2 & Vienna & 60 & 41 & 72 & 92 & 119 & 182 & 231 & 280 & 536 & 760 & 950 \\
\hline 3 & Berlin & 19 & 21 & 38 & 66 & 96 & 148 & 169 & 278 & 485 & 683 & 945 \\
\hline 4 & London & 88 & 108 & 110 & 143 & 162 & 167 & 176 & 273 & 383 & 657 & 945 \\
\hline 5 & Barcelona & 12 & 24 & 19 & 31 & 68 & 121 & 189 & 280 & 458 & 750 & 918 \\
\hline 6 & Singapore & 2 & 10 & 21 & 46 & 88 & 114 & 159 & 234 & 432 & 638 & 795 \\
\hline 7 & Madrid & 26 & 35 & 53 & 62 & 97 & 131 & 127 & 200 & 314 & 493 & 782 \\
\hline 8 & Lisbon & 8 & 11 & 12 & 26 & 52 & 91 & 139 & 209 & 358 & 521 & 692 \\
\hline 9 & Seoul & 4 & 8 & 17 & 28 & 55 & 103 & 154 & 231 & 383 & 586 & 691 \\
\hline 10 & Prague & 33 & 29 & 24 & 25 & 30 & 81 & 153 & 227 & 399 & 536 & 688 \\
\hline 11 & Amsterdam & 29 & 49 & 73 & 84 & 100 & 172 & 190 & 257 & 344 & 550 & 652 \\
\hline 12 & Copenhagen & 46 & 32 & 65 & 75 & 105 & 131 & 222 & 266 & 335 & 543 & 631 \\
\hline 13 & Brussels & 29 & 47 & 56 & 79 & 113 & 121 & 129 & 161 & 225 & 483 & 585 \\
\hline 14 & Beijing & 0 & 0 & 0 & 5 & 38 & 91 & 137 & 197 & 428 & 644 & 582 \\
\hline 15 & Hong Kong & 2 & 12 & 8 & 27 & 41 & 82 & 153 & 209 & 312 & 461 & 580 \\
\hline 16 & Dublin & 14 & 29 & 28 & 46 & 62 & 74 & 104 & 126 & 271 & 369 & 563 \\
\hline 17 & Rome & 39 & 43 & 34 & 49 & 76 & 99 & 117 & 211 & 314 & 490 & 560 \\
\hline 18 & Budapest & 18 & 35 & 26 & 54 & 97 & 149 & 220 & 216 & 381 & 481 & 558 \\
\hline 19 & Istanbul & 8 & 15 & 11 & 9 & 18 & 41 & 95 & 114 & 281 & 598 & 557 \\
\hline \multirow[t]{3}{*}{20} & Buenos Aires & 5 & 19 & 31 & 33 & 65 & 90 & 100 & 165 & 276 & 466 & 531 \\
\hline & Other & 1,197 & 1,906 & 3,004 & 4,434 & 6,265 & 8,768 & 12,055 & 18,195 & 28,213 & 42,655 & 51,282 \\
\hline & Total & 1,729 & 2,569 & 3,827 & 5,566 & 7,925 & 11,217 & 15,318 & 22,722 & 35,733 & 54,249 & 65,566 \\
\hline
\end{tabular}

\section{Conclusion}

Istanbul is a city with high recognition in the world. Today, Istanbul has a certain positive brand value that has naturally emerged in the fields of geography, finance, services, trade and tourism. The city has some important advantages and disadvantages compared with other global cities. The main advantages of the city are its location/accessibility, historical background, cultural heritage, transport infrastructure, young population, cost of living, and healthcare services. The main disadvantages of the city are environmental conditions, lack of open spaces and green areas, and insufficient R\&D studies and patents. In addition, the most obvious realities of the city, overcrowded construction, crowded population and traffic congestion create a very strong negative image and perception among the people who look at the city from outside and make the city's many positive features and beauty unnoticeable. 
Istanbul after the year of 2000 is a city whose global integration tendencies are getting stronger but consequently its internal tensions increase (Arlı, 2016b).

These internal tensions are leading to the dichotomy of global integration/local segregation. Human mobility in Istanbul is a good example of these tensions, and it shows social relocation and displacements within the city. While domestic immigrations to the city have always been higher than emigration from the city until 2015, there has been a reverse trend since 2015. In the last three years, the city's residents tend to migrate to other metropolises and cities in the country. However the city remains a point of attraction for students, international immigrants, tourists, sojourners and refugees.

The presence of international immigrants means for Istanbul to hold global labour power. The fact that international immigrants prefer Istanbul is a positive contribution to the global attractiveness of the city. It is useful to consider in detail how global labour power can be exploited in the upper and lower levels of Istanbul. While establishing a population policy for Istanbul, it should be taken into consideration that the city would always be a point of attraction for international immigrants. In this context, regular scientific researches/measurements on the qualifications and capabilities of permanent/temporary refugees should be carried out and the social integration policies pursued in the city should be sustained. Following such an approach on international migrants will bring about improvement in the socio-economic structure of the city.

As pointed in the previous chapters, Istanbul's efforts to be integrated with the global world have also triggered socio-spatial transformations in the central areas of the city, and to the expansion of the city in the east-west and north directions towards natural thresholds. The city needs to empower its position among other global cities without destroying its social fabric and transcending its natural thresholds.

\section{References}

Arlı, Alim (2016a) "Yükseköğretimde Büyüme, Farklılaşma ve Reorganizasyon: İstanbul Örneği (1980-2015)", Sosyoloji Konferansları, Vol.54, pp. 199.

Arlı, Alim (2016b) Dünya Ölçeğinde İstanbul, in Antik çağdan XXI. yüzyıla Büyük İstanbul Ansiklopedisi, Kültür A.Ş., İstanbul.

Baş, Ahmet, Paköz, Muhammed Ziya and Eren, Fatih (2018) The Economic and Environmental Impact of Istanbul's Grand Airport Project on the Urban Structure and Behaviour of Istanbul. Young Planners Workshop 2018. Paris, FRANCE: "European Council of Spatial Planners (ECTP-CEU)". p.38-52. ISBN:978-2-9601363-5-7

Çakır Zeytinoğlu, Filiz, Uydacı, Mert, Çağlayan Akay, Ebru, Değerli, Başak and Karabıyık Yerden, Nevin (2016) "istanbul'daki Alışveriş Merkezleri Üzerine Bir Araştırma: Kümeleme Analizi", Social Sciences Research Journal, Vol.5 No.1.

DGMM (2019a), "Residence Permits", available at: https://www.goc.gov.tr/icerik6/ikametizinleri 3633784709 icerik (accessed July 5, 2019).

\begin{tabular}{lcccc} 
DGMM & (2019b), "Temporary & Protection”, & available & at: \\
https://www.goc.gov.tr/icerik6/gecici-koruma & $363 \quad 378 \quad 4713$ icerik & (accessed July 5, \\
\hline 2019). &
\end{tabular}


DHMI (2018), "Airports Passenger Statistics 2018”, available at: https://www.dhmi.gov.tr/Lists/IstatistikList/Attachments/339/YOLCU.pdf (accessed July 1, 2019).

Eren, Fatih (2018) "Top government hands-on megaproject management: the case of Istanbul's grand airport", International Journal of Managing Projects in Business, Vol. aheadof-print, No. ahead-of-print DOI: https://doi.org/10.1108/IJMPB-02-2018-0020

Ericsson (2016), "Networked Society City Index", Networked Society Insights, available at: https://www.ericsson.com/en/trends-and-insights/networked-society-insights/city-index (accessed July 6, 2019)

Göymen, K. (2008) "Istanbul: Mega City Straddling Two Continents", Urban Research \& Practice, Vol.1 No.3, pp. 266-275.

Gürmen, E. (2016), "How Turkish Soap Operas Took Over The World”, The FADER, available at: http://www.thefader.com/2016/03/01/turkish-soap-operas (accessed May 8, 2019).

IBB (2017), "National and Regional Synthesis Report", Istanbul Metropolitan Municipality, 1/100.000 Istanbul Master Plan and 1/25.000 Development Plan Research and Application Project, Istanbul.

ICCA (2018), “A Modern History of International Association Meetings - Update 1963 2017”, available at: https://www.iccaworld.org/knowledge/benefit.cfm?benefitid=5230 (accessed June 15, 2019).

İstanbulSMD (2019), "Istanbul's Mega Projects", available at: http://en.megaprojeleristanbul.com/ (accessed July 2, 2019).

JLL (2019), "Global 300 Map”, Cities Research, Jones Lang LaSalle, available at: http://citiesresearch.jll.com/cities-research/cities/global300map (accessed July 7, 2019)

Kearney (2019), “Global Cities Report 2018", available at: https://www.atkearney.com/documents/20152/1136372/2018+Global+Cities+Report.pdf/2 1839da3-223b-8cec-a8d2-408285d4bb7c?t=1527106649606 (accessed July 3, 2019)

Kiriş̧̧i, Kemal (2007), "Turkey: A Country of Transition from Emigration to Immigration", Mediterranean Politics, Vol.12 No.1, pp. 91-97.

Looch, Cassam (2019), "The Rise and Rise of Turkish TV", available at: https://theculturetrip.com/europe/turkey/articles/the-rise-and-rise-of-turkishtv/ (accessed July 9, 2019).

Melamed, Ariana (2019), "The Turks Are Back, and They've Got All of Israel Addicted", Haaretz, available at: https://www.haaretz.com/israel-news/.premium.MAGAZINE-thebride-of-istanbul-turkey-back-in-israel-and-they-ve-got-everyone-addicted-1.6896105 (accessed May 11, 2019).

Ministry of Commerce (2018), "Foreign Trade Data by Provinces", Istanbul, available at: https://www.ticaret.gov.tr/istatistikler/dis-ticaret-istatistikleri/dis-ticaret-istatistikleri-ocakmayis-2019/illere-gore-dis-ticaret (accessed June 28, 2019) 
MMF (2018), "Global Power City Index", Institute for Urban Strategies. The Mori Memorial Foundation, available at: http://mori-m-foundation.or.jp/english/ius2/gpci2/index.shtml (accessed July 9, 2019)

Numbeo (2019), "Cost of Living in Istanbul”, available at: https://www.numbeo.com/cost-ofliving/in/Istanbul (accessed June 15, 2019)

OECD (2019), “ OECD Reports", available at: https://www.oecd.org/turkey/publicationsdocuments/reports/(accessed July 9, 2019).

Ozcan, Ceyhun \& Anaz, Necati (2016) Geography of Turkish Soap Operas: Tourism, Soft Power, and Alternative Narratives, in Egresi, Istvan (ed), Alternative Tourism in Turkey: Role, Potential Development and Sustainability, Springer (eBook).

Raza, Syed Hassan (2015), "Cultural impacts of Turkish Dramas on Life style of Pakistani House wives", Journal of Culture, Society and Development, Vol. 33.

Sobecki, Nichole (2010), "Turkish soap opera Noor brings tourist boom to Istanbul", the Guardian, available at: https://www.theguardian.com/world/2010/aug/13/soap-opera-noortourist-boom-turkey (accessed May 8, 2019).

TurkStat (2018) Turkish Annual Statistical Book, Ankara: TÜiK.

TurkStat (2016), "Foreign Trade Statistics", TÜiK Website, available at: http://www.tuik.gov.tr/PreTablo.do?alt id=1046 (accessed July 5, 2019)

TurkStat (2019a), "Tourism Statistics", available at: https://biruni.tuik.gov.tr/medas/?kn=74\&locale=tr (accessed June 20, 2019).

TurkStat (2019b), “Migration Statistics", available at: http://www.tuik.gov.tr (accessed June 11, 2019).

TOB (2019) "CORINE Land Use Data", available at: https://corinecbs.tarimorman.gov.tr/ (accessed July 3, 2019).

YOK (2019) "Higher Education Information Management System", available at: https://istatistik.yok.gov.tr/ (accessed July 4, 2019). 